\title{
First Look at the Venom of Naja ashei
}

\author{
Konrad Kamil Hus ${ }^{1}$ (i), Justyna Buczkowicz ${ }^{1}$, Vladimír Petrilla ${ }^{2,3}$, Monika Petrillová ${ }^{4}$, \\ Andrzej Lyskowski ${ }^{1}$ (iD), Jaroslav Legáth ${ }^{1,5}$ and Aleksandra Bocian ${ }^{1, *}$ \\ 1 Department of Biotechnology and Bioinformatics, Faculty of Chemistry, Rzeszow University of Technology, \\ Powstańców Warszawy 6, 35-959 Rzeszow, Poland; knr.hus@gmail.com (K.K.H.); czaporj@prz.edu.pl (J.B.); \\ alyskowski@prz.edu.pl (A.Ł.); Jaroslav.Legath@uvlf.sk (J.L.) \\ 2 Department of Physiology, University of Veterinary Medicine and Pharmacy, Komenského 73, \\ 04181 Kosice, Slovakia; petrillav@gmail.com \\ 3 Zoological Department, Zoological Garden Košice, Široká 31, 04006 Košice-Kavečany, Slovakia \\ 4 Department of General Education Subjects, University of Veterinary Medicine and Pharmacy, \\ Komenského 73, 04181 Kosice, Slovakia; monika.petrillova@uvlf.sk \\ 5 Department of Pharmacology and Toxicology, University of Veterinary Medicine and Pharmacy, \\ Komenského 73, 04181 Kosice, Slovakia \\ * Correspondence: bocian@prz.edu.pl; Tel.: +48-17-865-1287
}

Received: 31 January 2018; Accepted: 6 March 2018; Published: 8 March 2018

\begin{abstract}
Naja ashei is an African spitting cobra species closely related to N. mossambica and $N$. nigricollis. It is known that the venom of N. ashei, like that of other African spitting cobras, mainly has cytotoxic effects, however data about its specific protein composition are not yet available. Thus, an attempt was made to determine the venom proteome of N. ashei with the use of 2-D electrophoresis and MALDI ToF/ToF (Matrix-Assisted Laser Desorption/Ionization Time of Flight) mass spectrometry techniques. Our investigation revealed that the main components of analysed venom are 3FTxs (Three-Finger Toxins) and $\mathrm{PLA}_{2} \mathrm{~s}$ (Phospholipases $\mathrm{A}_{2}$ ). Additionally the presence of cysteine-rich venom proteins, $5^{\prime}$-nucleotidase and metalloproteinases has also been confirmed. The most interesting fact derived from this study is that the venom of $N$. ashei includes proteins not described previously in other African spitting cobras-cobra venom factor and venom nerve growth factor. To our knowledge, there are currently no other reports concerning this venom composition and we believe that our results will significantly increase interest in research of this species.
\end{abstract}

Keywords: Naja ashei; venom composition; 2-D electrophoresis; proteomics

\section{Introduction}

Electrophoretic techniques have been extensively used during past years to analyze complex mixtures of peptides and proteins like snake venoms. Rapid development of chromatographic techniques coupled with mass spectrometry is considered as standard in modern proteomics, however two-dimensional electrophoresis still remains an important method in analysis of venom variation, post-translational modifications or whole proteome mapping.

The African spitting cobras are widely distributed throughout the dry, open areas of sub-Saharan region. They are present from Senegal in the west to Somalia in the east, and from southern Egypt in the north to South Africa. This group comprises several snake species, including Naja nigricollis, N. katiensis and N. pallida. In 2007, N. ashei became another representative of African spitting cobras as Wüster and Broadley have classified it as a separate species [1]. In general, N. ashei venom has similar properties to the venoms of other African spitting cobras. It can cause local tissue damage, i.e., oedema, blistering and necrosis of the skin and subcutaneous connective tissue [2-5]. In addition, the venom is often spat into the eyes causing ophthalmic lesions [6]. After snake attack, a rapid development of tissue necrosis is observed, and in cases when antivenom treatment is administered too late, local 
lesions often lead to chronic ulceration, osteomyelitis, arthrodesis, hypertrophic scars, keloid formation and, in some chronic cases, malignant transformation [5].

Proteomic analysis of the spitting cobra venom composition revealed that in majority it consists of three-finger toxin (3FTx) and cytotoxic phospholipase $\mathrm{A}_{2}$ ( $\mathrm{PLA}_{2}$ ) molecules accounting, respectively, for $67-73 \%$ and $22-30 \%$ of the total venom proteins. The third largest group of proteins are the snake venom metalloproteinases (SVMPs) from PIII subfamily. There are also some other proteins that are less universal for all African spitting cobras, for instance: nucleotidases, cysteine-rich secretory proteins (CRISPs) or nawaprin [7].

So far, to our knowledge, no one has undertaken an analysis of the protein or peptide composition of Naja ashei venom. Therefore, in our study we present for the first time our initial venom composition results determined with the use of 2-D electrophoresis coupled with MALDI ToF/ToF mass spectrometry analysis.

\section{Results}

Distribution of spots on the obtained gels clearly indicated that the vast majority of proteins in the Naja ashei venom have a low molecular weight and clearly basic character (Figure 1). On the gel there were about 80 spots in the $\mathrm{pH}$ range of $3-10$. The exact number was impossible to determine because of the smears, spot trains and inaccurate separation of the most abundant spots.

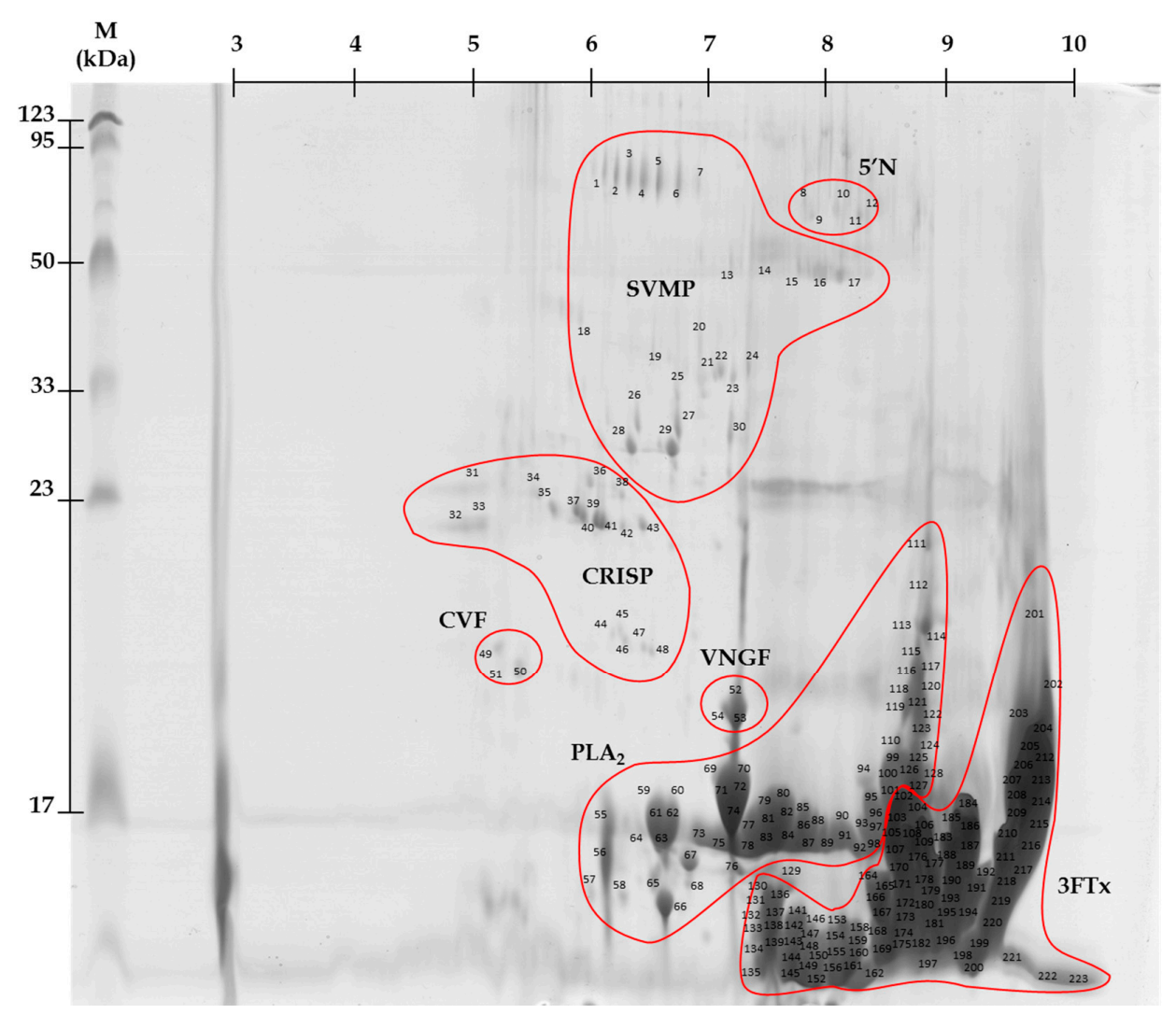

Figure 1. Representative 2-D protein map obtained from Naja ashei venom. $\mathbf{5}^{\prime} \mathbf{N}-$ Snake venom $5^{\prime}$-nucleotidase; SVMPs-Snake venom metalloproteinases; CRISPs-Cysteine-rich venom proteins; CVF-Cobra venom factor; VNGF-Venom nerve growth factor, $\mathbf{P L A}_{2} \mathrm{~S}$-Phospholipases $\mathrm{A}_{2}$; 3FTx - Snake three-finger toxin family.

The results for protein identification using MALDI ToF/ToF mass spectrometry are summarized in Table 1. Identified proteins were grouped into seven major groups (Figure 2). 
Table 1. Proteins identified in Naja ashei venom.

\begin{tabular}{|c|c|c|c|c|c|c|}
\hline Gel Area ${ }^{1}$ & Protein Name $^{2}$ & $\begin{array}{l}\text { Protein Accession Code, Source Organism as } \\
\text { Determined by Mascot and Spot Numbers }{ }^{2}\end{array}$ & Mass $[\mathrm{kDa}]^{3}$ & Score $^{4}$ & $m / z^{5}$ & $\begin{array}{c}\text { MS/MS-Derived } \\
\text { Sequence/Sequence Coverage }{ }^{6}\end{array}$ \\
\hline \multirow{7}{*}{ SVMP } & $\begin{array}{l}\text { Zinc metalloproteinase-disintegrin-like } \\
\text { cobrin }\end{array}$ & $\begin{array}{c}\text { Q9PVK7 (Naja kaouthia) } \\
20-24,27\end{array}$ & $\begin{array}{l}69 \\
69\end{array}$ & $\begin{array}{l}60 \\
81\end{array}$ & $\begin{array}{c}\text { PMF } \\
1280.722\end{array}$ & $\begin{array}{c}\text { SC } 9.5 \% \\
\text { DPSYGMVEPGTK }\end{array}$ \\
\hline & \multirow{3}{*}{$\begin{array}{l}\text { Zinc metalloproteinase-disintegrin-like } \\
\text { atrase A }\end{array}$} & \multirow{3}{*}{$\begin{array}{l}\text { D5LMJ3 (Naja atra) } \\
\quad 1-6\end{array}$} & 70 & 62 & 1087.732 & EHOEYLLR \\
\hline & & & 70 & 30 & 1073.517 & KGDDVSHCR \\
\hline & & & 70 & 44 & 1497.840 & ERPQCILNKPSR \\
\hline & \multirow{3}{*}{$\begin{array}{l}\text { Zinc metalloproteinase-disintegrin-like } \\
\text { atragin }\end{array}$} & \multirow{3}{*}{$\begin{array}{l}\text { D3TTC2 (Naja atra) } \\
14-17,25,26,28-30\end{array}$} & 71 & 24 & 1140.664 & DSCFTLNQR \\
\hline & & & 71 & 35 & 1155.607 & CGDGMVCSNR \\
\hline & & & 71 & 46 & 1476.894 & CPIMTNQCIALR \\
\hline \multirow{3}{*}{$5^{\prime} \mathrm{N}$} & \multirow{3}{*}{ Snake venom $5^{\prime}$-nucleotidase } & \multirow{3}{*}{$\begin{array}{l}\text { F8S0Z7 (Crotalus adamanteus) } \\
\quad 8-12\end{array}$} & 57 & 48 & 1523.801 & HGQGTGELLQVSGIK \\
\hline & & & 63 & 62 & 1389.797 & LTILHTNDVHAR \\
\hline & & & 65 & 32 & 1110.568 & QAFEHSVHR \\
\hline \multirow{4}{*}{ CRISP } & \multirow{2}{*}{$\begin{array}{l}\text { Cysteine-rich venom protein annuliferin } \\
\text { a (fragment) }\end{array}$} & P0DL14 (Naja annulifera) & 3.6 & 68 & 1168.696 & NVDFNSESTR \\
\hline & & $40,44-48$ & 3.6 & 96 & 1195.609 & EIVDLHNSLR \\
\hline & \multirow{2}{*}{ Cysteine-rich venom protein natrin 1} & Q7T1K6 (Naja atra) & 27 & 80 & 1553.910 & MEWYPEAASNAER \\
\hline & & $32,33,37-39,41-43$ & 27 & 45 & 1569.594 & MEWYPEAASNAER \\
\hline \multirow{2}{*}{$\mathrm{CVF}$} & \multirow{2}{*}{ Cobra venom factor } & Q91132 (Naja kaouthia) & 185 & 37 & 1306.709 & GICVAEPYEIR \\
\hline & & $49-51$ & 185 & 58 & 1337.885 & VNDDYLIWGSR \\
\hline \multirow{10}{*}{$\mathrm{PLA}_{2}$} & \multirow{2}{*}{ Acidic phospholipase A2 CM-I } & P00602 (Naja mossambica) & 14 & 60 & PMF & $32.2 \%$ \\
\hline & & $55,56,59-63,70,71$ & 14 & 110 & 1769.783 & CCQVHDNCYGEAEK \\
\hline & \multirow{3}{*}{ Basic phospholipase A2 1} & \multirow{3}{*}{$\begin{array}{c}\text { P00603 (Naja mossambica) } \\
57,58,65-68,72-78\end{array}$} & 14 & 60 & PMF & $32.2 \%$ \\
\hline & & & 14 & 46 & 987.512 & GTPVDDLDR \\
\hline & & & 14 & 72 & 1413.809 & LGCWPYLTLYK \\
\hline & \multirow{5}{*}{ Basic phospholipase A2 CM-III } & \multirow{5}{*}{$\begin{array}{c}\text { P00604 (Naja mossambica) } \\
79-89,91-93,95,101,113-121,123-127\end{array}$} & 14 & 90 & PMF & $55.9 \%$ \\
\hline & & & 14 & 99 & 1374.965 & YIDANYNINFK \\
\hline & & & 14 & 79 & 1512.841 & CCQVHDNCYEK \\
\hline & & & 14 & 193 & 2157.377 & CGAAVCNCDLVAANCFAGAR \\
\hline & & & 14 & 28 & 1282.633 & CTVPSRSWWHFANYGCYCGR \\
\hline \multirow{6}{*}{ VNGF } & \multirow{6}{*}{ Venom nerve growth factor } & \multirow{3}{*}{$\begin{array}{l}\text { P61898 (Naja atra) } \\
\quad 53,54\end{array}$} & 13 & 60 & 1127.664 & NPNPEPSGCR \\
\hline & & & 13 & 49 & 1648.000 & GNTVTVMENVNLDNK \\
\hline & & & 13 & 41 & 1415.821 & CKNPNPEPSGCR \\
\hline & & \multirow{3}{*}{$\begin{array}{c}\text { Q90W38 (Bothrops jararacussu) } \\
52\end{array}$} & 27 & 65 & 962.627 & QYFFETK \\
\hline & & & 27 & 71 & 1363.885 & ALTMEGNQASWR \\
\hline & & & 27 & 45 & 1379.914 & ALTMEGNQASWR \\
\hline
\end{tabular}


Table 1. Cont

\begin{tabular}{|c|c|c|c|c|c|c|}
\hline Gel Area ${ }^{1}$ & Protein Name $^{2}$ & $\begin{array}{l}\text { Protein Accession Code, Source Organism as } \\
\text { Determined by Mascot and Spot Numbers }{ }^{2}\end{array}$ & Mass $[k D a]^{3}$ & Score ${ }^{4}$ & $m / z^{5}$ & $\begin{array}{c}\text { MS/MS-Derived } \\
\text { Sequence/Sequence Coverage }\end{array}$ \\
\hline \multirow{10}{*}{ 3FTx } & \multirow{4}{*}{ Cytotoxin 1} & P01467 (Naja mossambica) [C] & 7 & 56 & PMF & $45 \%$ \\
\hline & & 103-105 & 7 & 68 & 1302.807 & CNQLIPPFWK \\
\hline & & P01468 (Naja pallida) [C] & 7 & 78 & PMF & $58.3 \%$ \\
\hline & & $139,144-147,166-192,200,204-220$ & 7 & 50 & 1091.463 & YMCCNTDK \\
\hline & \multirow{2}{*}{ Cytotoxin 2} & P01469 (Naja mossambica) $[\mathrm{C}]$ & 7 & 59 & PMF & $45 \%$ \\
\hline & & $193-196,221-223$ & 7 & 50 & 948.463 & GCIDVCPK \\
\hline & Cytotoxin 4 & $\begin{array}{l}\text { P01452 (Naja mossambica) [C] } \\
\quad 106-109,162,180,206\end{array}$ & 7 & 40 & 1060.609 & YVCCSTDR \\
\hline & Cytotoxin 5 & $\begin{array}{c}\text { P25517 (Naja mossambica) [C] } \\
109,142,148-157,159-163,180,206\end{array}$ & 7 & 39 & 1118.459 & YECCDTDR \\
\hline & Cytotoxin 11 & $\begin{array}{c}\text { P62390 (Naja annulifera) }[\mathrm{C}] \\
130,136,138-143,154,159,164\end{array}$ & 7 & 52 & 1020.337 & RGCAATCPK \\
\hline & Muscarinic toxin-like protein 2 & $\begin{array}{c}\text { P82463 (Naja kaouthia) }[\mathrm{M}] \\
131\end{array}$ & 7 & 69 & 1319.692 & GCAATCPIAENR \\
\hline
\end{tabular}

${ }^{1}$ Spot gel area name is the same as in Figures 1 and $2 ;{ }^{2}$ Protein name and database accession number of homologous proteins and organism from which protein identification originates. In the case of 3FTx cytotoxins: [C] cytotoxin activity, [M] muscarinic toxin-like activity (according to the UniProt database, www.uniprot.org). Spot numbers are related to Figure 1; ${ }^{3}$ The mass of molecule as reported by Mascot (Boston, MA, USA); ${ }^{4}$ Protein identification was performed using the Mascot search with probability based Mowse score. Ions score was $-10 \times \log (P)$, where $P$ was the probability that the observed match was a random event; ${ }^{5}$ Mass of precursor ion or information about PMF (Peptide Mass Fingerprinting) identification mode use; ${ }^{6}$ Peptide sequence derived from LIFT analysis (Autoflex Speed, Bruker Daltonics, Billerica, MA, USA). Identification of proteins by MS/MS method was conducted by comparing obtained sequences with sequences from database. In the case of PMF identification: SC—amino acid sequence coverage for the identified proteins. Collection of annotated mass spectra is available as a Supplementary Material. 


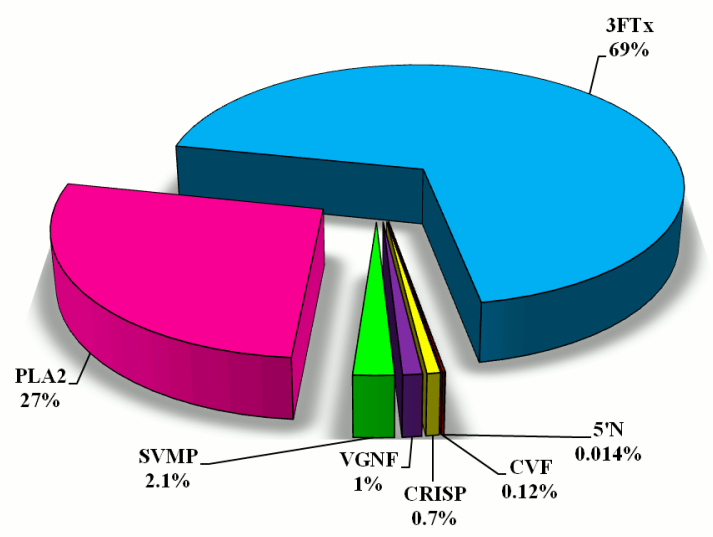

Figure 2. The percentage distribution of different protein groups in Naja ashei proteome calculated on the basis of \% Vol of particular spots on gels. Abbreviations are the same as in Figure 1.

Using the \%Vol of each spot on the gel, relative amounts of individual protein fractions in the venom of $N$. ashei were determined. Percentage distribution of protein groups is presented in Figure 2. According to this analysis, the most abundant proteins are cytotoxins belonging to snake three-finger toxins (almost $70 \%$ ). The second highly abundant group are phospholipases $\mathrm{A}_{2}(27 \%)$. The share of other groups of proteins: metalloproteinases, venom nerve growth factor, cysteine-rich venom proteins, cobra venom factor, snake venom $5^{\prime}$-nucleotidase does not exceed $5 \%$ of the total protein content (Figure 2).

\section{Discussion}

Proteomic analysis of the venoms of African species of spitting cobras has revealed similar properties and protein profiles [7]. We discovered seven groups of proteins, among which 3FTxs and phospholipases $\mathrm{A}_{2}$ were the most abundant. The remaining five groups of proteins (SVMPs, CRISPs, venom nerve growth factor, cobra venom factor and $5^{\prime}$-nucleotidases) together constitute less than $5 \%$ of the total proteins of Naja ashei venom. For this group of Elapidae the predominant share of cytotoxic 3FTx and PLA 2 molecules is distinctive. However, the minor contribution of SVMPs, CRISPs, and endonucleases was also described [7]. On the basis of this composition, it is likely that the major cytotoxins and $\mathrm{PLA}_{2} \mathrm{~S}$ are responsible for the predominant myo- and cytotoxic effects induced by these venoms (i.e., dermonecrosis) [8].

A large number of three-finger toxins interfere with cholinergic transmission in the peripheral and central nervous system, thus, they are classified to the neurotoxin group [9]. However, a large number of the 3FTxs also exhibit general cytolytic properties (i.e., disruption of the membrane bilayer by forming pores in the cellular surface or penetrating into the biological membranes and triggering different biological phenomena and, therefore, they are also referred to as cytolysins or cytotoxins) [10-13]. The most interesting from a pharmacological point of view is the fact that cytotoxins possess significant and selective anticancer activity by inducing apoptosis or necrosis of tumor cells [14-20]. It makes this group a very interesting object of investigation, especially since the intact proteins from Naja ashei have never been examined.

The second most abundant protein group in N. ashei venom are phospholipases $\mathrm{A}_{2}$ (Figure 2). In general, $\mathrm{PLA}_{2} \mathrm{~s}$ exhibit a wide variety of physiological and pathological effects. They undeniably play a role in the digestion of prey, but also exhibit a wide spectrum of pharmacological effects, such as neurotoxicity, cardiotoxicity, myotoxicity, and anticoagulant effect [21-27]. Interestingly, this group of proteins has also anticancer [28-32] and antimicrobial properties [33-36]. In N. ashei venom $\mathrm{PLA}_{2} \mathrm{~S}$ constitute $27 \%$ of all identified proteins, and this value is typical for all African spitting cobras [7].

The third group of proteins, distinctive for all African spitting cobras, are metalloproteinases. Their quantity in this group of snake venom ranges from 1.6 to 3.3\% [7], and in N. ashei metalloproteinases 
share $2.1 \%$ of total venom proteins. All identified metalloproteinases belong to PIII family, and are zinc-dependent enzymes degrading plasma proteins and the extracellular matrix surrounding blood vessels, leading to local and systemic haemorrhage and coagulopathy [37-39]. PIII-SVMPs are present in venoms of all venomous snakes; however, their proportion in Elapid venom is much lower than in Viperid $[40,41]$. This fact determined that elapid SVMPs are much less understood, although it is believed that local tissue damage, haemorrhage, and complement depletion, reported after N. nigricollis bites, are caused by SVMP activity [2,4]. Low content of metalloproteinases in venom could indicate their minor role in the pathophysiology of envenoming. However, some studies reported that their high enzymatic activity can vastly contribute to the detrimental effects of venom [38,39,42].

CRISPs were also detected in N. ashei venom (Figure 1), however their content is definitely small (Figure 2). They are widely distributed among different snake venoms, and in our earlier studies, we have detected them in Viperidae venoms [41,43]. Intriguingly, this group of non-enzymatic proteins is not typical for all African spitting cobra species. Earlier works indicated their presence only in N. nigricollis and N. katiensis venoms [7]. 5'-Nucleotidase seems to be more universal for this group of snakes, because it was detected in all species except N. nubiae [7]. Enzymes from this group were detected in venoms of several species, always in small quantities [41,44,45].

It is very interesting that we were able to identify two proteins not detected before in African spitting cobras venom. They are: cobra venom factor, with $0.12 \%$ share, and venom nerve growth factor, with $1 \%$ share of total venom proteins. A negligible amount of these proteins in the venom indicates that their impact on the pathology of envenoming is low, but these proteins are extremely interesting from a pharmacological point of view. Cobra venom factor depletes complement C3 protein, and thus inhibits inflammatory and immune responses. This protein could be potentially used in several human diseases treatment, for instance: myocardial ischemia reperfusion injury, age-related macular degeneration, arthritis, paroxysmal nocturnal haemoglobinuria or lymphoma [46], and carcinoma [47]. In turn, VNGF is important for the growth, development, differentiation, and survival of neurons both in the peripheral and the central nervous systems [48], and additionally it inhibits metalloproteinase-disintegrin proteins [49]. It is known that nerve growth factors interact with some cancer cells $[50,51]$, however the greatest hopes for their use lay in the treatment of neurodegenerative diseases [52-55].

This study shows that two-dimensional electrophoresis still can be used as an effective method for protein separation in analysis of snake venom proteome. Moreover, presented results clearly indicate that venom of Naja ashei is very similar to the closely related African spitting cobras. Nevertheless, the most interesting fact derived from this study is that the venom of $N$. ashei includes proteins not described so far in African spitting cobras. There are no other reports concerning this venom composition and we believe that our results will significantly increase interest in research of this species.

\section{Materials and Methods}

Pooled Naja ashei venom sample was obtained from two adult snakes (male and female), which were captured and officially imported from Kenya. Venom was extracted in the Pata breeding garden near Hlohovec (Slovakia), which had been designed for conservation of the reptiles' gene pool under the veterinary certificate No. CHEZ-TT-01. The breeding garden also serves as a quarantine station for imported animals and is an official importer of exotic animals from around the world, having the permission of the State Nature Protection of the Slovak Republic under the No. 03418/06, the trade with endangered species of wild fauna and flora and on amendments to certain laws under Law no. $237 / 2002 \mathrm{Z} . z$. After extraction, the venom was stored at $-20^{\circ} \mathrm{C}$ (transport temperature) and then moved to $-80^{\circ} \mathrm{C}$ for deep freezing.

The detailed procedure for proteomic analysis was described in our previous papers $[41,43]$. Protein concentration in crude venom was measured with 2-D Quant Kit (GE Healthcare, Little Chalfont, UK), using bovine serum albumin as a standard. The samples for isoelectrofocusing (IEF) were prepared by mixing $405 \mu \mathrm{g}$ of proteins with standard thiourea rehydration solutions 
containing IPG buffers 3-10 pH range (GE Healthcare). Separation was conducted on $17 \mathrm{~cm}$ ReadyStrip IPG Strips with 3-10 pH gradient (Bio-Rad, Hercules, CA, USA). After IEF, the strips were incubated in equilibration buffers; one containing 1\% DTT (for reduction); second containing 2.5\% IAA (for alkylation). Prior to SDS-PAGE (Sodium dodecyl sulfate-polyacrylamide gel electrophoresis), gel strips were placed onto the top of $13 \%$ polyacrylamide gels $(1.5 \times 255 \times 196 \mathrm{~mm})$. Roti ${ }^{\circledR}$-Mark PRESTAINED molecular weight marker (Roth, Karlsruhe, Germany) was used as a mass reference. After electrophoresis, the gels were incubated overnight in staining solution with colloidal Coomassie Brilliant Blue G-250. Quantitative analysis of individual groups of proteins was carried out in Image Master 2D Platinum software (GE Healthcare) using \%Vol parameter (a ratio of the volume of a particular spot to the total volume of all spots present in the gel). The final result is an average of the spots \%Vol obtained from three independent gels (technical repeats). In overall, about 200 samples were collected from 80 visible spots. Small spots were excised once, and thus each one contained a single sample. In turn, larger spots constituted for several samples due to multiple excision in different regions of the spot.

All samples were digested using Sequencing Grade Modified Trypsin (Promega, Madison, WI, USA). After digestion stage every sample was mixed in 1:1 ratio with the matrix. The matrix consisted of $\alpha$-cyano-4-hydroxycinnamic acid diluted in $50 \%$ acetonitrile with $0.1 \%$ trifluoroacetic acid. The obtained peptide mixtures were analyzed on MALDI-ToF/ToF MS (Autoflex Speed, Bruker Daltonics, Billerica, MA, USA). The spectrometer was working in positive ions mode with the reflectron. The analysed ion masses ranged between 700 and $3500 \mathrm{Da}$. Calibration of the spectrometer was carried out every four samples, using standards in the range of analyzed peptides (Peptide Calibration Standards II, Bruker Daltonics). The obtained mass spectra were compared to those present in SwissProt database (The UniProt Consortium, www.uniprot.org) with the use of Mascot software. The search parameters included: mass tolerance: $0.25 \mathrm{Da}$, one incomplete cleavage allowed, alkylation of cysteine by carbamidomethylation (fixed modification), and oxidation of methionine (variable modification). Moreover, some peptides were selected for analysis in MS/MS mode. The peptides were sequenced by laser-induced dissociation (LID) using LIFT ion source. The search parameters for MS/MS data included: mass tolerance for MS mode: $0.25 \mathrm{Da}$, mass tolerance for MS/MS mode: $0.5 \mathrm{Da}$, one incomplete cleavage allowed, alkylation of cysteine by carbamidomethylation (fixed modification), and oxidation of methionine (variable modification).

Supplementary Materials: The following are available online, Annotated MS/MS spectra of the identified proteins.

Author Contributions: A.B. performed 2-D electrophoresis, protein identification, and wrote the manuscript; A.Ł. and K.K.H. performed bioinformatic analysis; J.B. performed 2-D electrophoresis and prepare samples for MS analysis; J.L. coordinated experiment; V.P. caught animals in their natural habitat; M.P. assisted with handling and fixating the animals, as well as collecting snake venoms.

Conflicts of Interest: The authors declare no conflict of interest.

\section{References}

1. Wüster, W.; Broadley, D.G. Get an eyeful of this: A new species of giant spitting cobra from eastern and north-eastern Africa (Squamata: Serpentes: Elapidae: Naja). Zootaxa 2007, 1532, 51-68, E-ISSN 1175-5334.

2. Warrell, D.A.; Greenwood, B.M.; Davidson, N.M.; Ormerod, L.D.; Prentice, C.R. Necrosis, haemorrhage and complement depletion following bites by the spitting cobra (Naja nigricollis). Q. J. Med. 1976, 45, 1-22. [CrossRef] [PubMed]

3. Tilbury, C.R. Observations on the bite of the Mozambique spitting cobra (Naja mossambica mossambica). S. Afr. Med. J. 1982, 61, 308-313, E-ISSN 2078-5135. [PubMed]

4. Warrell, D.A. Clinical toxicology of snakebite in Africa and the Middle East/Arabian Peninsula. In Handbook of Clinical Toxicology of Animal Venoms and Poisons; Meier, J., White, J., Eds.; CRC Press: Boca Raton, FL, USA, 1995; pp. 433-492. ISBN 9780849344893.

5. World Health Organization. Guidelines for the Prevention and Clinical Management of Snakebite in Africa; WHO/AFR/EDM/EDP/10.01; WHO, Regional Office for Africa: Brazzaville, Congo, 2010. 
6. Warrell, D.A.; Ormerod, L.D. Snake venom ophthalmia and blindness caused by the spitting cobra (Naja nigricollis) in Nigeria. Am. J. Trop. Med. Hyg. 1976, 25, 525-529. [CrossRef] [PubMed]

7. Petras, D.; Sanz, L.; Segura, Á.; Herrera, M.; Villalta, M.; Solano, D.; Vargas, M.; León, G.; Warrel, D.A.; Theakston, R.D.; et al. Snake venomics of African spitting cobras: Toxin composition and assessment of congeneric cross-reactivity of the pan-African EchiTAb-Plus-ICP antivenom by antivenomics and neutralization approaches. J. Proteome Res. 2011, 10, 1266-1280. [CrossRef] [PubMed]

8. Rivel, M.; Solano, D.; Herrera, M.; Vargas, M.; Villalta, M.; Segura, Á.; Arias, A.S.; León, G.; Gutiérrez, J.M. Pathogenesis of dermonecrosis induced by venom of the spitting cobra, Naja nigricollis: An experimental study in mice. Toxicon 2016, 119, 171-179. [CrossRef] [PubMed]

9. Kini, R.M.; Doley, R. Structure, function and evolution of three-finger toxins: Mini proteins with multiple targets. Toxicon 2010, 56, 855-867. [CrossRef] [PubMed]

10. Konshina, A.G.; Boldyrev, I.A.; Utkin, Y.N.; Omel'kov, A.V.; Efremov, R.G. Snake cytotoxins bind to membranes via interactions with phosphatidylserine headgroups of lipids. PLoS ONE 2011, 6, e19064. [CrossRef] [PubMed]

11. Konshina, A.G.; Dubovskii, P.V.; Efremov, R.G. Structure and dynamics of cardiotoxins. Curr. Protein Pept. Sci. 2012, 13, 570-584. [CrossRef] [PubMed]

12. Dubovskii, P.V.; Konshina, A.G.; Efremov, R.G. Cobra cardiotoxins: Membrane interactions and pharmacological potential. Curr. Med. Chem. 2014, 21, 270-287. [CrossRef] [PubMed]

13. Gasanov, S.E.; Dagda, R.K.; Rael, E.D. Snake venom cytotoxins, phospholipase $\mathrm{A}_{2} \mathrm{~s}$, and $\mathrm{Zn}^{2+}$-dependent metalloproteinases: Mechanisms of action and pharmacological relevance. J. Clin. Toxicol. 2014, 4, 1000181. [CrossRef] [PubMed]

14. Feofanov, A.V.; Sharonov, G.V.; Dubinnyi, M.A.; Astapova, M.V.; Kudelina, I.A.; Dubovskii, P.V.; Rodionov, D.I.; Utkin, Y.N.; Arseniev, A.S. Comparative study of structure and activity of cytotoxins from venom of the cobras Naja oxiana, Naja kaouthia, and Naja haje. Biochem. Mosc. 2004, 69, 1148-1157. [CrossRef]

15. Feofanov, A.V.; Sharonov, G.V.; Astapova, M.V.; Rodionov, D.I.; Utkin, Y.N.; Arseniev, A.S. Cancer cell injury by cytotoxins from cobra venom is mediated through lysosomal damage. Biochem. J. 2005, 390, 11-18. [CrossRef] [PubMed]

16. Yang, S.H.; Chien, C.M.; Lu, M.C.; Lu, Y.J.; Wu, Z.Z.; Lin, S.R. Cardiotoxin III induces apoptosis in K562 cells through a mitochondrial-mediated pathway. Clin. Exp. Pharmacol. Physiol. 2005, 32, 515-520. [CrossRef] [PubMed]

17. Gomes, A.; Choudhury, S.R.; Saha, A.; Mishra, R.; Giri, B.; Biswas, A.K.; Debnath, A.; Gomes, A. A heat stable protein toxin (drCT-I) from the Indian Viper (Daboia russelli russelli) venom having antiproliferative, cytotoxic and apoptotic activities. Toxicon 2007, 49, 46-56. [CrossRef] [PubMed]

18. Chien, C.M.; Yang, S.H.; Chang, L.S.; Lin, S.R. Involvement of both endoplasmic reticulum-and mitochondria-dependent pathways in cardiotoxin III-induced apoptosis in HL-60 cells. Clin. Exp. Pharmacol. Physiol. 2008, 35, 1059-1064. [CrossRef] [PubMed]

19. Das, T.; Bhattacharya, S.; Biswas, A.; Gupta, S.D.; Gomes, A.; Gomes, A. Inhibition of leukemic U937 cell growth by induction of apoptosis, cell cycle arrest and suppression of VEGF, MMP-2 and MMP-9 activities by cytotoxin protein NN-32 purified from Indian spectacled cobra (Naja naja) venom. Toxicon 2013, 65, 1-4. [CrossRef] [PubMed]

20. Wu, M.; Ming, W.; Tang, Y.; Zhou, S.; Kong, T.; Dong, W. The anticancer effect of cytotoxin 1 from Naja atra Cantor venom is mediated by a lysosomal cell death pathway involving lysosomal membrane permeabilization and cathepsin B release. Am. J. Chin. Med. 2013, 41, 643-663. [CrossRef] [PubMed]

21. Barrington, P.L.; Yang, C.C.; Rosenberg, P. Cardiotoxic effects of Naja nigricollis venom phospholipase $\mathrm{A}_{2}$ are not due to phospholipid hydrolytic products. Life Sci. 1984, 35, 987-995. [CrossRef]

22. Stefansson, S.; Kini, R.M.; Evans, H.J. The basic phospholipase $\mathrm{A}_{2}$ from Naja nigricollis venom inhibits the prothrombinase complex by a novel nonenzymatic mechanism. Biochemistry 1990, 29, 7742-7746. [CrossRef] [PubMed]

23. Gowda, T.V.; Middlebrook, J.L. Effect of myonecrotic snake venom phospholipase $\mathrm{A}_{2}$ toxins on cultured muscle cells. Toxicon 1993, 31, 1267-1278. [CrossRef]

24. Kini, R.M. Structure-function relationships and mechanism of anticoagulant phospholipase $\mathrm{A}_{2}$ enzymes from snake venoms. Toxicon 2005, 45, 1147-1161. [CrossRef] [PubMed] 
25. Montecucco, C.; Gutiérrez, J.M.; Lomonte, B. Cellular pathology induced by snake venom phospholipase $\mathrm{A}_{2}$ myotoxins and neurotoxins: Common aspects of their mechanism of action. Cell. Mol. Life Sci. 2008, 65, 2897-2912. [CrossRef] [PubMed]

26. Lomonte, B.; Angulo, Y.; Sasa, M.; Gutiérrez, J.M. The phospholipase $\mathrm{A}_{2}$ homologues of snake venoms: Biological activities and their possible adaptive roles. Protein Pept. Lett. 2009, 16, 860-876. [CrossRef] [PubMed]

27. Doley, R.; Zhou, X.; Kini, R.M. Snake Venom Phospholipase $A_{2}$ Enzymes. In Handbook of Venoms and Toxins of Reptiles; Mackessy, S.P., Ed.; CRC Press: Boca Raton, FL, USA, 2010; pp. 173-205. ISBN 9780849391651.

28. Rodrigues, R.S.; Izidoro, L.F.; de Oliveira, R.J., Jr.; Sampaio, S.V.; Soares, A.M.; Rodrigues, V.M. Snake venom phospholipases $\mathrm{A}_{2}$ : A new class of antitumor agents. Protein Pept. Lett. 2009, 16, 894-898. [CrossRef] [PubMed]

29. Zouari-Kessentini, R.; Luis, J.; Karray, A.; Kallech-Ziri, O.; Srairi-Abid, N.; Bazaa, A.; Loret, E.; Bezzine, S.; El Ayeb, M.; Marrakchi, N. Two purified and characterized phospholipases $\mathrm{A}_{2}$ from Cerastes cerastes venom, that inhibit cancerous cell adhesion and migration. Toxicon 2009, 53, 444-453. [CrossRef] [PubMed]

30. Chen, K.C.; Liu, W.H.; Chang, L.S. Taiwan cobra phospholipase $\mathrm{A}_{2}$-elicited JNK activation is responsible for autocrine fas-mediated cell death and modulating Bcl-2 and Bax protein expression in human leukemia K562 cells. J. Cell. Biochem. 2010, 109, 245-254. [CrossRef] [PubMed]

31. Khunsap, S.; Pakmanee, N.; Khow, O.; Chanhome, L.; Sitprija, V.; Suntravat, M.; Lucena, S.E.; Perez, J.C.; Sánchez, E.E. Purification of a phospholipase $\mathrm{A}_{2}$ from Daboia russelii siamensis venom with anticancer effects. J. Venom. Res. 2011, 2, 42-51, E-ISSN 2044-0324. [PubMed]

32. Murakami, T.; Kamikado, N.; Fujimoto, R.; Hamaguchi, K.; Nakamura, H.; Chijiwa, T. A [Lys ${ }^{49}$ ] phospholipase $\mathrm{A}_{2}$ from Protobothrops flavoviridis venom induces caspase-independent apoptotic cell death accompanied by rapid plasma-membrane rupture in human leukemia cells. Biosci. Biotechnol. Biochem. 2011, 75, 864-870. [CrossRef] [PubMed]

33. Rodrigues, V.M.; Marcussi, S.; Cambraia, R.S.; de Araújo, A.L.; Malta-Neto, N.R.; Hamaguchi, A.; Ferro, E.A.; Homsi-Brandeburgo, M.I.; Giglio, J.R.; Soares, A.M. Bactericidal and neurotoxic activities of two myotoxic phospholipases $\mathrm{A}_{2}$ from Bothrops neuwiedi pauloensis snake venom. Toxicon 2004, 44, 305-314. [CrossRef] [PubMed]

34. Santamaría, C.; Larios, S.; Angulo, Y.; Pizarro-Cerda, J.; Gorvel, J.P.; Moreno, E.; Lomonte, B. Antimicrobial activity of myotoxic phospholipases $\mathrm{A}_{2}$ from crotalid snake venoms and synthetic peptide variants derived from their C-terminal region. Toxicon 2005, 45, 807-815. [CrossRef] [PubMed]

35. Xu, C.; Ma, D.; Yu, H.; Li, Z.; Liang, J.; Lin, G.; Zhang, Y.; Lai, R. A bactericidal homodimeric phospholipases $\mathrm{A}_{2}$ from Bungarus fasciatus venom. Peptides 2007, 28, 969-973. [CrossRef] [PubMed]

36. Samy, R.P.; Stiles, B.G.; Gopalakrishnakone, P.; Chow, V.T. Antimicrobial proteins from snake venoms: Direct bacterial damage and activation of innate immunity against Staphylococcus aureus skin infection. Curr. Med. Chem. 2011, 18, 5104-5113. [CrossRef] [PubMed]

37. Fox, J.W.; Serrano, S.M. Structural considerations of the snake venom metalloproteinases, key members of the M12 reprolysin family of metalloproteinases. Toxicon 2005, 45, 969-985. [CrossRef] [PubMed]

38. Gutierrez, J.M.; Rucavado, A.; Escalante, T.; Díaz, C. Haemorrhage induced by snake venom metalloproteinases: Biochemical and biophysical mechanisms involved in microvessel damage. Toxicon 2005, 45, 997-1011. [CrossRef] [PubMed]

39. Gutierrez, J.M.; Rucavado, A.; Escalante, T. Snake venom metalloproteinases. Biological roles and participation in the pathophysiology of envenomation. In Handbook of Venoms and Toxins of Reptiles; Mackessy, S.P., Ed.; CRC Press: Boca Raton, FL, USA, 2010; pp. 115-138. ISBN 9780849391651.

40. Li, S.; Wang, J.; Zhang, X.; Ren, Y.; Wang, N.; Zhao, K.; Chen, X.; Zhao, C.; Li, X.; Shao, J.; et al. Proteomic characterization of two snake venoms: Naja naja atra and Agkistrodon halys. Biochem. J. 2004, 384, $119-127$. [CrossRef] [PubMed]

41. Bocian, A.; Urbanik, M.; Hus, K.; Łyskowski, A.; Petrilla, V.; Andrejčáková, Z.; Petrillová, M.; Legáth, J. Proteomic Analyses of Agkistrodon contortrix contortrix Venom Using 2D Electrophoresis and MS Techniques. Toxins 2016, 8, 372. [CrossRef] [PubMed]

42. Nielsen, V.G.; Frank, N.; Matika, R.W. Carbon monoxide inhibits hemotoxic activity of Elapidae venoms: Potential role of heme. BioMetals 2018, 31, 51-59. [CrossRef] [PubMed] 
43. Bocian, A.; Urbanik, M.; Hus, K.; Łyskowski, A.; Petrilla, V.; Andrejčáková, Z.; Petrillová, M.; Legáth, J. Proteome and peptidome of Vipera berus berus venom. Molecules 2016, 21, 1398. [CrossRef] [PubMed]

44. Tan, C.H.; Tan, K.Y.; Fung, S.Y.; Tan, N.H. Venom-gland transcriptome and venom proteome of the Malaysian king cobra (Ophiophagus hannah). BMC Genom. 2015, 16, 687. [CrossRef] [PubMed]

45. Trummal, K.; Samel, M.; Aaspõllu, A.; Tõnismägi, K.; Titma, T.; Subbi, J.; Siigur, J.; Siigur, E. 5' -Nucleotidase from Vipera lebetina venom. Toxicon 2015, 93, 155-163. [CrossRef] [PubMed]

46. Vogel, C.W.; Fritzinger, D.C. Cobra venom factor: Structure, function, and humanization for therapeutic complement depletion. Toxicon 2010, 56, 1198-1222. [CrossRef] [PubMed]

47. Terpinskaya, T.I.; Ulashchik, V.S.; Osipov, A.V.; Tsetlin, V.I.; Utkin, Y.N. Suppression of Ehrlich carcinoma growth by cobra venom factor. Dokl. Biol. Sci. 2016, 470, 240-243. [CrossRef] [PubMed]

48. Reichardt, L.F. Neurotrophin-regulated signalling pathways. Philos. Trans. R. Soc. Lond. B. Biol. Sci. 2006, 361, 1545-1564. [CrossRef] [PubMed]

49. Wijeyewickrema, L.C.; Gardiner, E.E.; Gladigau, E.L.; Berndt, M.C.; Andrews, R.K. Nerve growth factor inhibits metalloproteinase-disintegrins and blocks ectodomain shedding of platelet glycoprotein VI. J. Biol. Chem. 2010, 285, 11793-11799. [CrossRef] [PubMed]

50. Walsh, E.M.; Kim, R.; Del Valle, L.; Weaver, M.; Sheffield, J.; Lazarovici, P.; Marcinkiewicz, C. Importance of interaction between nerve growth factor and $\alpha 9 \beta 1$ integrin in glial tumor angiogenesis. Neuro-Oncology 2012, 14, 890-901. [CrossRef] [PubMed]

51. Osipov, A.V.; Terpinskaya, T.I.; Kryukova, E.V.; Ulaschik, V.S.; Paulovets, L.V.; Petrova, E.A.; Blagun, E.V.; Starkov, V.G.; Utkin, Y.N. Nerve growth factor from cobra venom inhibits the growth of Ehrlich tumor in mice. Toxins 2014, 6, 784-795. [CrossRef] [PubMed]

52. Dechant, G.; Barde, Y.A. The neurotrophin receptor $\mathrm{p} 75^{\mathrm{NTR}}$ : Novel functions and implications for diseases of the nervous system. Nat. Neurosci. 2002, 5, 1131-1136. [CrossRef] [PubMed]

53. He, X.L.; Garcia, K.C. Structure of nerve growth factor complexed with the shared neurotrophin receptor p75. Science 2004, 304, 870-875. [CrossRef] [PubMed]

54. Salehi, A.; Delcroix, J.D.; Swaab, D.F. Alzheimer's disease and NGF signalling. J. Neural Transm. 2004, 111, 323-345. [CrossRef] [PubMed]

55. Tuszynski, M.H.; Thal, L.; Pay, M.; Salmon, D.P.; Bakay, R.; Patel, P.; Blesch, A.; Vahlsing, H.L.; Ho, G.; Tong, G.; et al. A phase 1 clinical trial of nerve growth factor gene therapy for Alzheimer disease. Nat. Med. 2005, 11, 551-555. [CrossRef] [PubMed]

Sample Availability: Samples are not available from the authors.

(C) 2018 by the authors. Licensee MDPI, Basel, Switzerland. This article is an open access article distributed under the terms and conditions of the Creative Commons Attribution (CC BY) license (http:/ / creativecommons.org/licenses/by/4.0/). 